\title{
LEGISLATIVE AND FINANCIAL ASPECTS OF SERVICES OF REGIONAL EDUCATION PROVIDED BY MUNICIPALITIES
}

\author{
PRÁVNE A FINANČNÉ ASPEKTY \\ SLUŽIEB REGIONÁLNEHO ŠKOLSTVA \\ POSKYTOVANÝCH OBCAMI
}

Eva Balážová *, Eva Lázárová**

\section{Introduction to the issues}

The existence of heterogeneous local self-governments' centre, during the decision-making, the local self-governments are exposed to the pressure of potentially mobile households and they are trying to make the best offer of public services ${ }^{(1)}$. In practice, the relevance of this model is limited; despite it shows that the mobility of consumers creates a space for acquisition of higher effect of decentralization of public admin-

(1) BOADWAY, R. 2001. Inter-Governmental Foscal Relations: The Facilitator of Fiscal Decentralization. Constitutional Political Economy. 2001. $121 \mathrm{~s}$.

\section{Abstract (EN)}

The process of decentralisation of public administration was based on the transfer of competences from state administration to municipalities and on the setting of new conditions for financing of municipalities. In the process of decentralization of public administration and fiscal decentralization, the range of original and transferred competences, as well as the tasks of municipalities and the corresponding instruments of financing, were set there by mutual agreement between the state bodies and the local self-government. The transfer of competences on municipalities in the field of education was not a simple process. The first steps in the management of schools and educational facilities did not entail without problems. Many of the misunderstandings grew up mainly from a lack of knowledge of the relevant laws governing the specific educational and training activities, operation, financing, personnel and material-technical provision of schools and educational facilities. The aim of the contribution is legislative and financial definition of current system of provision of services by municipalities in the Slovak Republic in the field of regional education, because this area is complicated and disorganized the laws dealing with education and its financing have undergone many amendments. The following compact and comprehensive issues can serve as a framework for further research.

\section{Keywords (EN)}

financing of services, regional education istration, especially in the case of the local public services. The problem of fiscal decentralisation is the determination of the optimal amount of provided public service and the optimal size of society that uses it ${ }^{(2)}$.

On the other hand, the local public services are not usually relevant in their consumption; with the increasing number of residents the quality of services can get worse. The Economic Theory of Clubs, which is the theory of mixed public goods, describes that. The theory is based on the question: Why the goods, also known as club goods, should be the public goods, or more precisely why they should be supplied by

(2) ROVAZNíKOVÁ, R. 2009. Financování měst, obcí a regionu teorie a praxe, Praha: GRADA Publishing, a. s., 2009. 304 s. ISBN 978-80-247-2789-9.

\section{Abstrakt (SK)}

Proces decentralizácie verejnej správy pozostával aj z presunu kompetencií z orgánov štátnej správy na obce a z nastavenia nových podmienok financovania obcí. V procese decentralizácie verejnej správy a fiškálnej decentralizácie bol po vzájomnej dohode orgánov štátu a územnej samosprávy nastavený rozsah prenesených a originálnych pôsobností a úloh obcí a tomu zodpovedajúce nástroje ich financovania. Prechod kompetencií na obce $v$ oblasti školstva nebol jednoduchým procesom. Prvé kroky v správe škôl a školských zariadení sa neobišli bez problémov. Mnoho nedorozumení vznikalo predovšetkým z nedostatočnej znalosti príslušných právnych noriem upravujúcich osobitosti výchovnej a vzdelávacej činnosti, prevádzky, financovania, personálneho a materiálno-technického zabezpečenia činnosti škôl a školských zariadení. Cielom príspevku je legislatívne a finančné vymedzenie súčasného systému poskytovania služieb obcami SR v oblasti regionálneho školstva, nakolk'ko táto oblast' je komplikovaná, neprehladná, zákony týkajúce sa školstva a jeho financovania prešli mnohými novelizáciami. Takto ucelene spracované problematika môže slúžit ako rámec pre další výskum.

\section{Klưčové slová (SK)}

financovanie služieb, regionálne školstvo

* Slovak University of Agriculture in Nitra

** Slovak University of Agriculture in Nitra 
public sector? The Economic Theory of Clubs is the theory of cooperative membership, where the purpose of club goods is the usage of the economies of scale in production of club goods and the participation on the costs of providing of club goods ${ }^{(3)}$. The result will be the allocation of public goods, which should vary from place to place depending on the collective preferences of people living in each area ${ }^{(4)}$. The roots of this idea of spatial allocation are based on the principle of liberal economics: the public good is provided only in the case if the local population requires it. Otherwise, its providing is based on "the personal reasons". Bauchanova's hypotheses then proclaim that some areas will have extensive public sector, while the others have just a small one, it all depends on the preferences and pensions they have $e^{(5)}$.

\section{Legislative aspects of services of regional education provided by municipalities}

The competences in the field of education have been transferred to municipalities from state government bodies in the process of decentralisation of public administration by Act no. 416/2001 Coll. on Transfer of Some Competencies from State Government Bodies to Municipalities and Higher Territorial Units, whose the provisions relating to education came into force on 1 July 2002.

The school system of the Slovak Republic offers preschool education in kindergartens, general education at primary schools, general and vocational education at secondary schools up to the highest education at the universities.

Based on the previous perspective, the school system in the Slovak Republic consists of three basic levels of schools:

a) primary degree (kindergartens, primary schools),

b) secondary degree (secondary schools),

c) tertiary degree (universities).

From the view of competences, the school system of the Slovak Republic has the following classification:

a) regional education (kindergartens, primary schools, secondary schools) - transferred and original competences of the local self-government,

b) higher education - (state, public and private universities) - competences of the state.

The schools, which offer primary and secondary education, along with educational facilities, represent so called regional education. In the article, we deal with the regional education that includes the system of schools and the system of educa-

(3) JíLEK, M. 2008. Fiskální decentralizace, teorie a empirie. Praha: ASPI a. s., 2008. 426 s. ISBN 978-80-7357-355-3.

(4) CSISZÁRIK-KOCSIR, Á. 2010: A helyi oktatásirányítási és szervezési döntésekben szerepet játszó tényezők bemutatása egy kvantitatív kutatás eredményeinek tükrében Humánpolitikai Szemle, 2010, július-augusztus, 63. - 74.old., ISSN 0865-7009.

(5) ROSEnblOOM, D. H. et al. 2009. Public Administration Understanding Management, Politics, and Law in the Public Sector. New York: McGraw-Hill, 2009. 580 s. ISBN 978-007126381-8. tional facilities, which are defined by Act no. 245/2008 Coll. on Upbringing and Education. Under this law, the system of schools is made up of these kinds of schools:

- schools, in which the education is deemed to be a permanent preparation for profession: primary school, grammar school, specialized secondary school, conservatory, schools for children and students with special educational and training needs - primary school for students with health disability, secondary school for students with health disability, practical school, vocational school.

- schools, in which the education is not deemed to be a permanent preparation for profession: kindergarten, kindergarten for students with health disability, elementary art school, language school.

The system of educational facilities consists of:

- school educational facilities (school club of children, school centre for leisure activities, free-time centre, dormitory, school farm, centre of special practice),

- special educational facilities (diagnostic centre, re-education centre, therapeutic and educational sanatorium),

- school facilities of educational consulting and prevention (centre of pedagogical and psychological consulting and prevention, centre of special pedagogical consulting),

- purpose-built school facilities (outdoor school facility, school catering facilities - school canteen, centre of services for schools).

Under Act no. 596/2003 Coll. on State Administration in Education and School Self-Government, the school, educational facility, centre of practical training and workplace of practical training could be established just after their integration into the network and they should be established by:

- municipality,

- Self-Governing District,

- District Office in seat of region,

- church or religious society recognized by state,

- another natural person or legal entity.

The education acquired in schools, which have been established by different founders, is equivalent. The schools and educational facilities may also carry out business activities, especially in the form of rental properties; however, it must not be in contradiction with the fulfilment of their mission. The schools, educational facilities and centres of practical training, which are established in the form of network, shall have the right to carry out education and training and they have the right to financial security under Act no. 597/2003 Coll. on Financing of Primary Schools, Secondary Schools and Educational Facilities, and on amendments and supplements to certain laws. 


\section{Financing of services of regional education provided by municipalities in the Slovak Republic}

The significant component of reform of regional education in the Slovak Republic was the introduction of multi-source financing, i.e. the schools should be financed also from other sources, not just from the main source. Because of that, in addition to the traditional source, that is the state budget, there are other sources which enter to the process of financing, such as sources of Higher Territorial Units, municipalities, business sphere, non-governmental organisations and so on.

Since 1 January 2013, the state budget has financed:

a) from the Budget Chapter of Ministry of Education, Science, Research and Sport of the Slovak Republic: schools, in which the education is deemed to be a permanent preparation for profession in the scope of Higher Territorial Units,

b) from the Budget Chapter of Ministry of Finance of the Slovak Republic:

- schools, in which the education is deemed to be a permanent preparation for profession in the scope of municipality, ecclesiastical founder, private founder and the District Office in seat of region (up to 31 December 2012 - Regional School Office),

- kindergartens for children with special educational and training needs in the scope of the District Office in seat of region (up to 31 December 2012 - Regional School Office),

- educational facilities in the scope of the District Office in seat of region (up to 31 December 2012 - Regional School Office).

Financing is based on the normative principle and legislatively it is adjusted by Act no. 597/2003 Coll. on Financing of Primary Schools, Secondary Schools and Educational Facilities, as amended; and by Government Regulation of the Slovak Republic no. 630/2008 Coll., which appointed details of the allocation of financial sources from the state budget for schools and educational facilities, and on amendments and supplements to certain laws.

Under Act no 597/2003 Coll., and on amendments and supplements to certain laws, the finances are provided to:

1. schools, in which student are preparing for profession, in the scope of:

a) municipalities, Higher Territorial Units and the District Office in seat of region,

b) church or religious society recognized by state,

c) another natural person or legal entity.,

2. kindergartens for children with special educational and training needs in the scope of the District Office in seat of region,

3. educational facilities in the scope of the District Office in seat of region.

The share of state taxes distributed by municipalities are used for financing:

- under Act no. 564/2004 Coll. on Budget Determination of Income Tax Yields to Regional Self-Government, as amended and Government Regulation of the Slovak Republic no. 668/2004 Coll. on Distribution of Income Tax Revenues to Regional Self-Government, as amended: kindergartens, elementary art schools, language schools and educational facilities in the scope of municipality and Higher Territorial Units, since 1 January 2005,

- under Act no. 596/2003 Coll. on State Administration in Education and School Self-Government, as amended: kindergartens, elementary art schools, language schools and educational facilities in the scope of ecclesiastical and private founders, since 1 January 2007.

Under Act no. 596/2003 Coll., financing is used by:

A) municipalities: costs of upbringing and education of children;

- in elementary art schools, language schools, kindergartens and educational facilities in their scope,

- up to the age of 15 in elementary art schools, language schools, kindergartens and educational facilities in the scope of church or religious society recognized by state and another natural person or legal entity.

B) Higher Territorial Units: costs of upbringing and education of children (pupils and students):

- in elementary art schools, language schools and educational facilities in their scope,

- up to the age of 15 in elementary art schools, language schools and educational facilities in the scope of church or religious society recognized by state and another natural person or legal entity.

The details of financing of schools and educational facilities, which are financed under Act no. 596/2003 Coll., are adjusted by Generally Binding Regulations of municipalities.

The distribution of financial resources to municipalities and Higher Territorial Units is adjusted by:

- Act no. 564/2004 Coll. on Budget Determination of Income Tax Yields to Regional Self-Government, and on amendments and supplements to certain laws,

- Government Regulation of the Slovak Republic no. 668/2004 Coll. on Distribution of Income Tax Revenues to Regional Self-Government, as amended.

The financial resources are provided to founders of schools and educational facilities, which are financed under Act no. 597/2003 Coll., by the District Office in seat of region.

The founders of schools and educational facilities are given:

a) normative financial resources,

b) non-normative financial resources.

Normative financial resources cover the reimbursement of costs wages and salaries including premiums for compulsory health insurance, social insurance, contribution to retirement pension saving and operating costs.

The schools, in which the education is deemed to be a permanent preparation for profession, are financed normatively since 2004. The normative way of financing is applied to the financing of these schools identically, regardless of their founder. It includes the following schools:

- primary schools, 
- secondary schools,

- primary schools for students with special educational and training needs,

- secondary schools for students with special educational and training needs,

- vocational schools,

- practical schools.

Normative financial resources are allocated to the portion of the financial resources intended for the standardized annual expenditures of personnel costs (the wages and salaries, including the insurance and the contribution of employer to the employees' insurance companies); and for the standardized annual expenditures of the educational and training process and operating costs.

The allocation of financial resources, which are from the Budget Chapter of Ministry of Finance for the founders of public schools for a calendar year, is based on the normative contribution for individual schools in the scope of the founder for the calendar year. The normative contribution for a school for the calendar year is determined by a number of its students and by the norm per a student in appropriate category of school.

The normative contribution for a school for the calendar year is the sum of the normative contribution for a current calendar year and the normative contribution for a new school year.

The norm determines an annual amount of contribution per one student. It is not uniformed for all schools; it depends on the kind and the type of a school, personnel intensity of field of study, the form of study, the language of instruction and also a size of a school should be taken into account.

In the period from January to August of a calendar year, the most significant is the number of students in accordance with the situation at 15 September of the previous calendar year; and in the period from September to December, the most significant is the number of students in accordance with the situation at 15 September of the calendar year, in which the survey is conducted. The norm is the sum of wage norm and operational norm.

The original educational competences are financed by municipalities from the shares of personal income taxes, which are remitted to municipalities by state each month. These incomes of municipalities are considered to be own income of municipality in accordance with the legislation in force.

Table 1 shows significant decrease of personal income taxes that were collected in year 2010 compared with the other two analyzed years. This situation can be attributed to the impacts of crisis. Simultaneously, the number of recalculated students has been increased; according to Reports on Management, it was caused by private free-time centres, which declared unrealistically high numbers of students.

Table 2 summarizes the overview of volume of normative and non-normative financial resources provided to schools in the period of years 2009-2011 from the Budget Chapter of Ministry of Education, Science, Research and Sport. The data

Table1: The development of personal income taxes in state budget with the impact to original educational competences for municipalities in years $2009-2011$

\begin{tabular}{|c|c|c|c|c|c|c|}
\hline \multirow{2}{*}{ Year } & $\begin{array}{c}\text { Revenue of } \\
\text { personal income } \\
\text { tax in } €\end{array}$ & $\begin{array}{c}\text { Year change } \\
\text { in \% }\end{array}$ & $\begin{array}{c}40 \% \text { of revenues } \\
\text { - education }\end{array}$ & $\begin{array}{c}\text { Recalculated } \\
\text { number of } \\
\text { students totally }\end{array}$ & $\begin{array}{c}\text { Amount per } \\
\text { recalculated } \\
\text { student in } €\end{array}$ & $\begin{array}{c}\text { Year change } \\
\text { in } \%\end{array}$ \\
\cline { 2 - 7 } & 1 & 2 & $3=40 \%$ from 1 & 4 & $5=3 / 4$ & 6 \\
\hline 2009 & 1207018000 & 103,82 & 482807200 & 7829054 & 61,669 & 102,45 \\
\hline 2010 & 995642000 & 82,49 & 398256800 & 8219808 & 48,451 & 78,57 \\
\hline 2011 & 1180188000 & 118,54 & 472075200 & 8003027 & 58,987 & 121,75 \\
\hline
\end{tabular}

Source: own elaboration according to Reports on Management in years 2009-2011

Table 2: Normative and non-normative financial resources provided to schools in $€$

\begin{tabular}{|l|c|c|c|}
\hline Indicator & 2009 & 2010 & 2011 \\
\hline Normative & 1195903625 & 1213174911 & 1198350897 \\
\hline Non-normative & 44074962 & 44362795 & 51560300 \\
\hline Totally & 1239978587 & 1257537706 & 1249911197 \\
\hline
\end{tabular}

Source: own elaboration according to Reports on Management in years 2009 - 2011

Table 3: Provided normative and non-normative financial resources per student of school in $€$

\begin{tabular}{|l|r|r|r|}
\hline Indicator & 2009 & 2010 & 2011 \\
\hline Total costs in $€$ & 1239978527 & 1257537706 & 1249911197 \\
\hline Number of founders & 1801 & 1796 & 1786 \\
\hline Number of schools & 3239 & 3225 & 3181 \\
\hline Number of student to 15.9. & 785570 & 764473 & 743518 \\
\hline Total costs per student of school in $€$ & 1578 & 1644 & 1681 \\
\hline
\end{tabular}

Source: own elaboration according to Reports on Management in years 2009 - 2011 
for each year were investigated from Reports on Management. The table shows that the amount of provided financial resources has not changed significantly.

The effect of the amount of normative and non-normative financial resources in the relation to the number of students, founders and schools is presented by Table 3 .

The information from Table 3 indicates that the number of founders is lower each year, especially in the case where the founder of school, in which the education is deemed to be a permanent preparation for profession, is the municipality. On the one hand, the total costs per student in the period 2009 - 2011 are increasing; on the other hand, the number of student is decreasing. This economically undesirable situation resulted from unfavourable demographic development is a problem for a number of schools, because the decrease of the number of students usually lead to the cancellation of classes in schools. In classes with decreasing number of students, the personnel and operating costs do not change and forasmuch as the student is a bearer of financial resources, the finances, which are provided to schools, are not sufficient for covering the cost of their functioning.

\section{Summary}

The regional education, which is provided by local selfgovernment, is a field whose results decisively influence the development of each society. They affect it in the positive way as long as the education is working, or in the negative way, if it does not work. The efficiency of school system is influenced by several factors. The most important are the system of financing, the network of schools and educational facilities, the system of governance, the availability of information for all stakeholders and the level of bureaucracy.

The local self-governments are considered to be the corner-stone of school system from the point of view of their founding competences in the field of education, but also the range of the activities in this area. The performance and quality of competences in regional education are, due to the law, in responsibility of municipalities, regardless of whether it is the transferred performance of state administration or the original domain; regardless of whether the founder of school is municipality or another non-public founder. Some of the sources of risks and problems of nowadays school system of regional education include a lack of transparency, because the system incorporates many sections (District Offices, municipalities, schools and educational facilities, Ministry of Finance of the Slovak Republic and Ministry of Education, Science, Research and Sport of the Slovak Republic) that communicate that should lead to the increase of likelihood of errors and simultaneously the financial flows are frag- mented; but also an inadequate institutional capacity. The other problems of regional education include the differences resulting from different positions of the founder (public, private, religious). Basically, it is all about the possibilities of obtaining the financial resources and the purposes of their use.

This article is supported by Cultural and Educational Grant Agency of the Ministry of Education, Science, Research and Sport of the Slovak Republic on the basis of the project Economy and Management of Public Services under the contract no.031SPU-4/2013.

\section{References:}

(1) BOADWAY, R. 2001. Inter-Governmental Foscal Relations: The Facilitator of Fiscal Decentralization. Constitutional Political Economy. 2001. $121 \mathrm{~s}$.

(2) CSISZÁRIK-KOCSIR, Á. 2010: A helyi oktatásirányitási és szervezési döntésekben szerepet játszó tényezők bemutatása egy kvantitatív kutatás eredményeinek tükrében Humánpolitikai Szemle, 2010, július-augusztus, 63.-74.old., ISSN 08657009.

(3) JíLEK, M. 2008. Fiskální decentralizace, teorie a empirie. Praha: ASPI a. s., 2008. 426 s. ISBN 978-80-7357-355-3.

(4) PROVAZNíKOVÁ, R. 2009. Financování měst, obcí a regionu - teorie a praxe, Praha: GRADA Publishing, a. s., 2009. 304 s. ISBN 978-80-247-2789-9.

(5) ROSENBLOOM, D. H. et al. 2009. Public Administration Understanding Management, Politics, and Law in the Public Sector. New York: McGraw-Hill, 2009. 580 s. ISBN 978-007126381-8.

\section{Legislative sources:}

(1) Act no. 416/2001 Coll. on the Transfer of Some Competencies from State Government Bodies to Municipalities and Higher Territorial Units

(2) Act no. 245/2008 Coll. on Upbringing and Education.

(3) Act no. 596/2003 Coll. on State Administration in Education and School Self-Government.

(4) Act no. 597/2003 Coll. on Financing of Primary Schools, Secondary Schools and Educational Facilities.

(5) Act no. 564/2004 Coll. on Budget Determination of Income Tax Yields to Regional Self-Government.

\section{Contact address/ Kontaktná adresa}

Ing. Eva Balážová, PhD.

Department of Public Administration, Faculty of European Studies and Regional Development, SUA in Nitra, e-mail: eva.balazova@uniag.sk Ing. Eva Lázárová, PhD.,

Center of International Programmes, Faculty of European Studies and Regional Development, SUA in Nitra, e-mail: eva.lazarova@uniag.sk 